\title{
Bermain aplikasi gadget berhubungan dengan keterlambatan perkembangan bicara dan bahasa pada balita
}

\author{
Kadek Bayu Suryawan, ${ }^{1}$ Lie Tanu Merijanti ${ }^{2}$
}

\begin{abstract}
ABSTRAK
\section{LATAR BELAKANG}

Gadget merupakan salah satu media informasi dan teknologi yang berkembang pesat dan telah membuat penggunanya menjadi ketergantungan, bahkan balita. Penggunaan gadget secara berlebihan dan tidak tepat dapat menimbulkan dampak berupa keterlambatan bicara atau bahasa. Di Indonesia jumlah keterlambatan bicara dan bahasa pada balita mencapai $10 \%$. Tujuan penelitian ini untuk mengetahui hubungan intensitas penggunaan gadget dengan keterlambatan perkembangan aspek bicara dan bahasa pada balita.
\end{abstract}

\section{METODE}

Penelitian ini menggunakan metode analitik observasional dengan pendekatan cross-sectional terhadap 100 responden yang memenuhi kriteria inkulsi maupun eksklusi. Pengumpulan data dilakukan melalui wawancara menggunakan kuesioner intensitas penggunaan gadget dan kuesioner pra skrining perkembangan pada bulan Oktober-Desember 2019 di TK Kelurahan Tomang, Jakarta Barat. Analisis data dilakukan dengan uji Chi-square dengan tingkat kemaknaan yang digunakan $\mathrm{p}<0.05$.

\section{HASIL}

Dengan total 100 responden, didapatkan 18 orang (18\%) intensitas penggunaan gadget rendah, 29 orang $(29 \%)$ intensitas penggunaan gadget sedang dan 53 orang (53\%) dengan intensitas penggunaan gadget tinggi. Responden dengan keterlambatan perkembangan aspek bicara dan bahasa sebanyak 39 orang (39\%) dan 61 orang (61\%) lainnya tidak mengalami keterlambatan perkembangan aspek bicara dan bahasa. Hasil analisis Chi-square menunjukkan hubungan intensitas penggunaan gadget dengan keterlambatan perkembangan aspek bicara dan bahasa pada balita memiliki nilai signifikansi $(\mathrm{p}=0.002)$.

\section{KESIMPULAN}

Intensitas penggunaan gadget berhubungan dengan keterlambatan perkembangan aspek bicara dan bahasa pada balita.

Kata kunci: intensitas gadget, keterlambatan perkembangan bicara dan bahasa, balita
${ }^{1}$ Program Studi Kedokteran, Fakultas Kedokteran Universitas Trisakti, Jakarta, Indonesia ${ }^{2}$ Departemen Ilmu Kedokteran Kerja, Fakultas Kedokteran Universitas Trisakti, Jakarta, Indonesia

\section{Korespondensi:}

Lie Tanu Merijanti

Departemen Ilmu Kedokteran

Kerja, Fakultas Kedokteran

Universitas Trisakti, Jakarta, Indonesia

Jalan Kyai Tapa (Kampus B)

Usakti, Grogol, Indonesia 11440

Email: liemerijanti@trisakti.ac.id

J Biomedika Kesehat 2021;4(4):157-

163

DOI: 10.18051/JBiomedKes.2021.

v4.157-163

pISSN: 2621-539X / eISSN: 2621-5470

Artikel akses terbuka (open access) ini didistribusikan di bawah lisensi Creative Commons Attribution 4.0 International (CC-BY 4.0) 


\section{ABSTRACT}

\section{Playing gadget applications is related to speech and language development delays in toddlers}

\section{BACKGROUND}

Gadgets are a medium of information and technology that is growing rapidly and it has made its users depend on it, even toddlers. Excessive and improper use of gadgets can impact delayed speech or language. In Indonesia the number of delays in speech and language in toddlers reaches $10 \%$. The purpose of this study is to determine the relationship between the intensity on using gadget with developmental delay on speech and language aspects in toddler.

\section{METHODS}

This study used an observational analytic method with a cross sectional approach to 100 respondents who met the inclusion and exclusion criteria. Data collection was carried out through interviews using gadget use intensity questionnaires and developmental pre-screening questionnaires in period October-December 2019 in kindergarten Tomang, West Jakarta. Data analysis was performed using the Chi-square with the limit of significance was $\mathrm{p}<0.05$.

\section{RESULTS}

With the total of 100 respondents, 53 respondents (53\%) had low gadget use intensity, 29 (29\%) had moderate intensity of gadget use and $18(18 \%)$ had high gadget use intensity. Respondents with delays in the development of aspects of speech and language are 39 respondents (39\%) and the other 61 respondents $(61 \%)$ did not experience delays in the development of aspects of speech and language. The Chi-square analysis showed significant relationship between intensity using gadget and delay in the development of aspects of speech and language $(\mathrm{p}=0.002)$.

\section{CONCLUSION}

The intensity of the use of gadgets is related to the developmental delay on speech and language aspects in toddler.

Keywords: gadget intensity, delay on speech and language, toddler

\section{PENDAHULUAN}

Masa anak di bawah lima tahun merupakan periode penting dalam tumbuh kembang anak karena pertumbuhan dasar yang berlangsung pada masa balita akan memengaruhi dan menentukan perkembangan anak selanjutnya. Seperti diketahui bahwa umur di bawah lima tahun merupakan periode keemasan (golden age), karena terjadi optimalisasi proses tumbuh kembang dan pada periode 2-4 tahun pertama, menunjukkan peningkatan yang cepat dalam jumlah dan kompleksitas perkembangan bicara dan bahasa. ${ }^{(1,2)}$

Keterlambatan bicara merupakan salah satu masalah perkembangan yang paling sering terjadi pada anak berusia di bawah 5 tahun. Secara umum, keterlambatan bicara adalah kondisi di mana kemampuan komunikasi seorang tidak sesuai dengan anak seusianya. $^{(3)}$ Di Indonesia sendiri jumlah kasus keterlambatan bicara dan bahasa pada anak mencapai $10 \%$. $^{(4)}$

Berdasarkan hasil penelitian yang dilakukan Handayani dan Amin menunjukkan bahwa $36.7 \%$ anak prasekolah mengalami gangguan perkembangan bahasa. (5) Penelitian lain yang dilakukan oleh Mardiana menunjukkan bahwa sebesar 8.2\% anak usia 1-3 tahun mengalami gangguan perkembangan bicara dan bahasa. ${ }^{(6)}$ Penelitian lain mengatakan bahwa keterlambatan bicara jika tidak segera ditangani maka akan memberikan efek jangka panjang seperti kesulitan membaca, kesulitan untuk berkomunikasi, kesulitan dalam hal akademik, dan lain sebagainya. ${ }^{(7)}$

Kemajuan teknologi dan informasi berkembang pesat di dunia pada akhir-akhir ini. Bangsa Indonesia merupakan salah satu bangsa yang ikut terlibat dalam kemajuan media informasi dan teknologi. ${ }^{(8)}$ Gadget merupakan salah satu media informasi dan teknologi yang berkembang pesat dan dapat 
diterima di kalangan masyarakat, sehingga telah membuat penggunanya menjadi ketergantungan, baik pada orang dewasa maupun pada anak-anak, termasuk balita. ${ }^{(9)}$ Penggunaan gadget dapat berupa komputer, smartphone, tablet, dan video game. ${ }^{(10)}$ Penyajian berbagai macam aplikasi yang menarik seperti video daring, game bahkan aplikasi pelajaran pada gadget, membuat intensitas penggunaan gadget menjadi lebih lama bahkan berlebihan. ${ }^{(11)}$ Penggunaan aplikasi gadget secara berlebihan dan tidak tepat dapat menimbulkan dampak negatif, antara lain berupa keterlambatan bicara atau bahasa, gangguan perhatian, kegelisahan, depresi di masa kecil, dan dampak negatif pada karakter. ${ }^{(12)}$

Beberapa penelitian mengaitkan intensitas penggunaan gadget dengan keterlambatan perkembangan aspek bicara dan bahasa. Penelitian yang dilakukan oleh Calorina et al menyatakan bahwa terdapat hubungan intensitas penggunaan gadget dengan keterlambatan perkembangan aspek bicara dan bahasa. ${ }^{(13)}$ Berbeda dengan penelitian sebelumnya, penelitian yang dilakukan oleh Meta Keumala menyatakan bahwa tidak terdapat gangguan perkembangan aspek bicara dan bahasa pada anak yang menggunakan gadget durasi kurang dari 2 jam perhari, frekuensi satu minggu sekali. ${ }^{(14)}$

Berdasarkan permasalahan yang telah diuraikan di atas, maka penulis ingin mengetahui hubungan antara intensitas bermain menggunakan gadget dan perkembangan aspek bicara dan bahasa pada balita terutama pada siswa kelompok bermain dan taman kanak-kanak (TK).

\section{METODE}

Penelitian ini menggunakan metode studi observasional, dengan desain crosssectional. Penelitian ini melibatkan 100 balita yang berada di empat TK Kelurahan Tomang Jakarta Barat periode Oktober-Desember 2019. Populasi penelitian merupakan orang tua atau pengasuh yang memiliki anak berusia 24 bulan sampai $<60$ bulan bulan dari empat TK tersebut. Sampel penelitian diambil menggunakan teknik cluster random sampling, dengan memilih secara acak 10 subjek dari kelas kelompok bermain (KB) dan 15 subjek dari kelas Taman Kanak -kanak (TK A) dari masing-masing sekolah TK tersebut, sehingga diperoleh 100 responden. Pemilihan sampel untuk kelas KB menggunakan absensi ganjil, sedangkan untuk kelas TK A menggunakan absensi genap. Tiap individu di dalam kelompok yang terpilih akan diambil sebagai sampel apabila memenuhi kriteria inklusi dan eksklusi yaitu orang tua atau pengasuh yang memiliki anak usia 24 bulan sampai $<60$ bulan, pernah menggunakan gadget, bersedia menjadi responden dengan persetujuan orang tua atau pengasuh, tidak menderita otitis media , tuli dan gangguan penglihatan, serta tidak mempunyai kelainan kongenital, seperti sindrom Down, palatoschisis, dan labioschisis.

Pengambilan data dilakukan melalui wawancara kepada responden menggunakan kuesioner intensitas penggunaan gadget untuk mengetahui durasi penggunaan gadget dalam satu hari dan frekuensi pemakaian gadget dalam seminggu. Penjumlahan skor dari durasi dan frekuensi dipakai untuk menentukan intensitas penggunaan gadget. Ada 3 kategori intensitas penggunaan gadget, yaitu intensitas 
rendah (skor 1-2) jika durasi 1-30 menit/ hari (skor 1) dan atau frekuensi pemakaian 1-3 hari /minggu (skor 1); intensitas sedang jika durasi 31-60 menit/hari (skor 2) dan atau frekuensi pemakaian 4-6 hari/minggu (skor 2); intensitas penggunaan tinggi jika durasi lebih dari 60 menit/hari (skor 3) dan atau frekuensi setiap hari (skor 3). ${ }^{(15)}$ Kuesioner praskrining perkembangan digunakan untuk menilai perkembangan aspek bicara dan bahasa, diisi dengan bantuan oarng tua/pengasuh untuk membantu anak dalam menjawab ataupun mengerjakan instruksi yang terdapat pada kuesioner, di mana kuesioner yang dipergunakan disesuaikan dengan usia dari balita yang dinilai. Perkembangan aspek bicara dan bahasa dikatakan normal jika balita dapat mengerjakan seluruh tugas perkembangan sesuai usianya, dan dikategorikan terlambat jika tidak dapat mengerjakan tugas-tugas perkembangan sesuai usianya. ${ }^{(16)}$ Data yang terkumpul diolah dalam Microsoft Excel, kemudian dianalisis menggunakan uji Chisquare. Penelitian ini telah lolos kaji etik riset dari Komisi Etik Riset Fakultas Kedokteran Universitas Trisakti dengan Nomor 56/KERFK/VII/2019.

\section{HASIL}

Pada Tabel 1, dapat dilihat responden didominasi oleh jenis kelamin laki-laki (60\%). Dari 100 balita yang menjadi responden rentang usia didominasi oleh usia 48 bulan2 sampai $<54$ bulan yaitu sebesar $40 \%$. Lebih dari setengah jumlah total responden memiliki intensitas penggunaan gadget dalam kategori tinggi, yaitu 53 responden (53\%). Terdapat 39 responden (39\%) memiliki keterlambatan perkembangan bicara dan bahasa. Hasil penelitian menunjukkan aplikasi yang mendominasi dan lebih banyak digunakan oleh balita adalah video Youtube, yaitu sebanyak 65 responden (65\%). Sebanyak 54 responden (54\%) memberikan respon tidak peduli pada sekitar ketika sedang menggunakan gadget.

Tabel 1. Distribusi karakteristik responden $(n=100)$

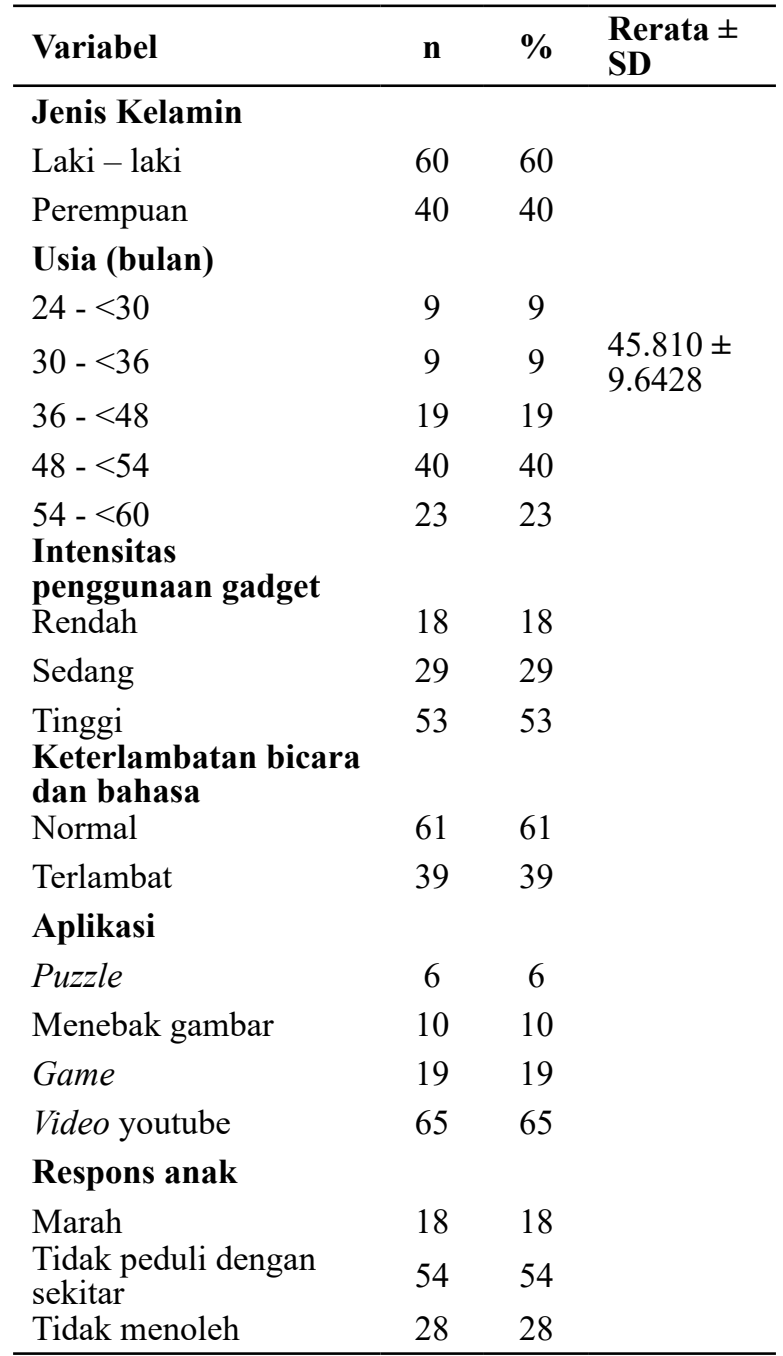

Keterangan: $\mathrm{n}=$ jumlah; $\%=$ persentase

Tabel 2 menggambarkan hubungan intensitas penggunaan gadget dengan keterlambatan perkembangan bicara dan bahasa. Hasil menunjukkan lebih banyak balita yang memiliki perkembangan bicara dan bahasa yang normal. Pada responden dengan intensitas penggunaan gadget yang tinggi, lebih banyak responden yang 
Tabel 2. Hubungan intensitas penggunaan gadget dengan keterlambatan perkembangan bicara dan bahasa

\begin{tabular}{lccc}
\hline \multirow{2}{*}{ Variabel } & Perkembangan bicara dan bahasa & p value \\
\cline { 2 - 3 } & $\begin{array}{c}\text { Normal } \\
\mathbf{n}(\%)\end{array}$ & $\begin{array}{c}\text { Terlambat } \\
\mathbf{n}(\%)\end{array}$ & \\
\hline Intensitas penggunaan gadget & $13(21.4)$ & $5(12.8)$ & $0.002^{\text {a }}$ \\
Rendah & $24(39.3)$ & $5(12.8)$ & $29(74.4)$ \\
Sedang & $24(39.3)$ & 29 & \\
Tinggi & & & \\
\hline
\end{tabular}

Keterangan: $\mathrm{a}=$ Uji statistik Chi-square $\mathrm{p}<0.05 ; \mathrm{n}=$ jumlah responden; $\%=$ persentase

mengalami keterlambatan perkembangan bicara dan bahasa, yaitu sebesar 29 responden. Terdapat 5 responden yang memiliki intensitas penggunaan gadget sedang mengalami keterlambatan berbahasa dan bicara. Pada intensitas penggunaan gadget ringan juga terdapat 5 responden yang mengalami keterlambatan berbahasa dan bicara. Hasil uji Chi-square, didapatkan nilai $\mathrm{p}=0.002$, sehingga dapat disimpulkan terdapat hubungan yang bermakna antara intensitas penggunaan gadget dengan keterlambatan perkembangan bicara dan bahasa pada balita.

\section{PEMBAHASAN}

Pada penelitian kami didapatkan 18 responden (18\%) memiliki intensitas penggunaan gadget rendah, 29 responden (29\%) intensitas sedang, dan 53 responden (53\%) dengan intensitas pemakaian tinggi. Saat menggunakan aplikasi gadget sebagian besar responden menunjukkan respons tidak peduli dengan sekitar dan tidak mengalihkan pandangannya dari layar gadget. Penggunaan gadget dengan durasi lebih dari satu jam per hari berhubungan bermakna dengan keterlambatan bicara dan bahasa. ${ }^{(17)}$

Studi yang kami lakukan mendapatkan 39 responden (39\%) mengalamiketerlambatan bicara dan bahasa. Penelitian yang dilakukan di klinik khusus tumbuh kembang menjumpai sebanyak 69.6\% anak berusia antara 1336 bulan yang mengalami keterlambatan bicara. $^{(18)}$ Perkembangan yang berlangsung pada masa balita akan mempengaruhi dan menentukan perkembangan anak selanjutnya, di mana perkembangan bicara dan bahasa merupakan indikator dari perkembangan anak. Keterlambatan dalam kemampuan berbahasa dapat mempengaruhi kemampuan kognitif, motorik, psikologis, dan emosi. ${ }^{(19)}$ Hampir dapat dipastikan bahwa anak yang mengalami keterlambatan bicara dan bahasa ke depannya akan mengalami kesulitan belajar atau lebih dikenal dengan istilah learning disabilities. ${ }^{(20)}$ Penelitian kami mendapatkan adanya hubungan yang bermakna antara intensitas penggunaan gadget dengan keterlambatan berbicara dan bahasa. Pada responden yang mengalami keterlambatan berbicara dan bahasa dijumpai 87 orang menggunakan gadget dengan intensitas penggunaan sedang dan tinggi. Penggunaan gadget dengan intensitasi tinggi membuat anak tidak berinteraksi terhadap orang lain, padahal berinteraksi dengan orang merupakan tahap pembelajaran komunikasi yang berpengaruh terhadap perkembangan bicara dan bahasa pada balita. $(12,20)$ Penelitian yang dilakukan oleh Lin et al menunjukkan bahwa durasi menggunakan gadget mempengaruhi perkembangan bahasa dan bicara pada anak. ${ }^{(19)}$ 
Kemampuan bicara dan berbahasa merupakan dasar bagi seorang anak untuk berinteraksi dan belajar. Ada beberapa faktor yang dapat memengaruhi perkembangan bicara dan bahasa seorang anak yaitu, bilingualism, kelainan sejak lahir, hingga penggunaan gadget. ${ }^{(6)}$ Anak usia di bawah lima tahun yang menggunakan gadget dengan intensitas rendah menunjukkan perkembangan yang sesuai dengan usianya, hanya yang menggunakan gadget dengan intensitas tinggi yang mengalami gangguan perkembangan. Hal ini karena penggunaan gadget yang berlebihan menyebabkan anak cenderung malas beraktivitas dan tidak peka dengan lingkungan, sehingga memiliki pengaruh besar terhadap perkembangan sosialisasi dan kemandirian anak yang berdampak pada keterlambatan bicara dan bahasa. ${ }^{(21)}$ Hasil yang berbeda didapatkan oleh Han Pin yang menyatakan bahwa tidak terdapat hubungan antara intensitas penggunaan gadget dengan keterlambatan bicara dan bahasa. Penelitian mereka mendapatkan adanya hubungan antara penggunaan gadget intensitas tinggi dengan masalah emosional dan perilaku balita yaitu gejala cemas atau depresi, gejala somatik, gejala penarikan sosial, masalah perhatian, dan perilaku agresif.(22) Penelitian lain mengatakan bahwa memberikan akses untuk menggunakan gadget pada anak usia dini dapat memberikan dampak positif dan negatif. Anak bisa memperoleh ketrampilan motorik yang lebih baik, meningkatkan kemampuan kognitif dan kompetitif, tapi di sisi lain juga berdampak negatif berupa keterlambatan berbicara, kurangnya perhatian, gangguan belajar bahkan dapat berakibat gangguan mental yang akan mempengaruhi karakter mereka di kemudian hari. ${ }^{(14)}$

Pada studi ini kami memiliki keterbatasan antara lain dengan desain cross-sectional kurang dapat menampilkan hubungan sebab akibat antara pemakaian gadget dan perkembangan bicara, kemudian kami tidak mengikutsertakan faktor-faktor lain yang turut mempengaruhi keterlambatan perkembangan aspek bicara dan bahasa seperti pola pengasuhan orang tua dan faktor sosial ekonomi keluarga.

\section{KESIMPULAN}

Dari penelitian ini dapat disimpulkan bahwa intensitas penggunaan gadget pada balita TK di Kelurahan Tomang didominasi dengan intensitas penggunaan gadget tinggi sebesar 53\%. Insiden kejadian keterlambatan perkembangan bicara dan bahasa adalah sebesar 39\%. Studi ini mendapatkan hasil bahwa terdapat hubungan bermakna antara intensitas penggunaan gadget dengan keterlambatan perkembangan bicara dan bahasa. Orang tua penting untuk mengatur waktu dalam bermain gadget pada anak usia dini sehingga tidak mengakibatkan gangguan dalam perkembangan aspek bicara dan bahasa yang akan berdampak terhadap pembentukan karakter di masa depan.

\section{KONFLIK KEPENTINGAN}

Tidak terdapat konflik kepentingan dalam penelitian ini.

\section{REFERENSI}

1. Gunawan, Gladys, Fadlyana E, et al. Hubungan status gizi dan perkembangan anak usia 1-2 tahun. Sari Pediatri. 2011;13(2). doi: 10.14238/ sp13.2.2011.142-6

2. Toghyani R, Sharafi SF, Sharafi SH, et al. Check the status of the development of childer under age 5 in rural areas of Isfahan using the ASQ questionnaire 
in 2021-2013 year. J Med Life. 2015;8(Spec Iss 4):169-173. PMID: 28316726

3. Shetty P. Speech and language delay in children: a review and the role of a pediatric dentist. J Indian Soc Pedod Prev Dent. 2012;30(2):103-8. doi: 10.4103/0970-4388.99979

4. Gunawan LM, Wijana, Pratiwi YS. Oto-Acoustic Emission and Auditory Brainstem Response Profile in Children with speech delay at Dr. Hasan Sadikin General Hospital Bandung. AMJ. 2016;3(2):265. doi: 10.15850/amj.v3n2.771

5. Handayani A, Samiasih A. Hubungan tingkat pengetahuan orang tua tentang stimulasi verbal dengan perkembangan bahasa pada anak prasekolah di TK PGRI 116 Bangetayu Wetan. FIKkes 2013;6(2):76-82.

6. Mardiana, Siska S, Indanah. Komunikasi orang tua dan bilingual berhubungan dengan perkembangan bahasa padarnak usia todller [Internet]. Prosiding of the 3 Universty Research Colloquium; 2016:593-603,.UMS, Surakarta. Available from: http://hdl.handle.net/11617/6929

7. Heidi D, Nelson, Nygren P, et al. Screening for speech and language delay in preschool children: Systematic evidence review for the US preventive services task force. Pediatrics 2006;(117):e298319. doi:10.1542/peds.2005-1467

8. Ameliola S, Nugraha DH. Perkembangan media informasi dan teknologi terhadap anak dalam era globalisasi [Internet]. Prosiding The 5 th International Conference on Indonesian Studies: "Ethnicity and Globalization";2013 :362-371; Malang, Universitas Brawijaya. Available from: http://icssis.files.wordpress.com/2013/09/20130229.pdf

9. Wijoyono VV, Negara INS, A Hendro. Perancangan iklan layanan masyarakat penggunaan gadget bijaksana pada anak usia 3-5 tahun Di Surabaya. Jurnal DKV Adiwarna 2015;1(6):1-11.

10. Subarkah MA. Pengaruh gadget terhadap perkembangan anak. Rausyan Fikr 2019;15(1):12636.

11. Novitasari W, Khotimah N. Dampak penggunaan gadget terhadap interaksi sosial anak usia 5-6 tahun. Jurnal PAUD Teratai 2016;5(3):2.

12. Sundus $M$. The impact of using gadgets on children. J Depress Anxiety [Internet]. 2018;7(1):296. Available from: https://www.omicsonline.org/ open-access/the-impact-of-using-gadgets-on-child ren-2167-1044-1000296-96313.html

13. Calorina L, Pawito, Prasetya H. The effect of gadget use on child development: A path analysis evidence from Melawi, West Kalimantan. JMOH. 2020;5(1):110-119. doi: 10.26911/ thejmch.2020.05.01.12

14. Keumala M, Yoestara M, Zaiyana P. The Impact of Gadget and Internet on The Implementation of Character Education on Early Childhood. In: Proceeding of the Internasional Conference on the Roles of Parents in Shaping Children's Characters. 2018. p. 313-25.

15. Nurmasi A. Hubungan intensitas penggunaan gadget dengan keterlambatan perkembangan pada aspek bicara dan bahasa pada balita di Kelurahan Tambakrejo Surabaya. Surabaya: Program Studi Pendidikan Bidan Universitas Airlangga; 2016.

16. Kementerian Kesehatan Republik Indonesia. Pedoman pelaksanaan stimulasi, deteksi dan intervensi dini tumbuh kembang anak di tingkat pelayanan kesehatan dasar. Jakarta: Kemenkes RI;
2013.

17. Kamal M, Syajriani N, Misdayanti. Gadget as Risk Factor to Speech and Language Delay in Autism Children. KEMAS. 2020;16(1)36:36-43. doi: 10.15294/kemas.v16i1.21875

18. Dewanti A, Widjaja JA, Tjandrajani A, et al. Karakteristik keterlambatan bicara di klinik khusus tumbuh kembang Rumah Sakit Anak dan Bunda Harapan Kita tahun 2008 - 2009. Sari Pediatri. 2012;14(4):230-4. doi: 10.14238/ sp14.4.2012.230-4

19. Lin LY, Cherng RJ, Chen YJ, et al. Effects of television exposure on developmental skills among young children. Infant Behav Dev. 2015;38:20-6. doi: 10.1016/j.infbeh.2014.12.005

20. Wijaya S. Efektivitas pelatihan indentifikasi dini keterlambatan bicara pada anak usia prasekolah untuk meningkatkan kompetensi pedagogik guru PAUD. Seminar Nasional Psikologi UMS 2015. Semarang: UMS; 2015. p.118-126.

21. Fajariyah SN, Suryawan A, Atika. Dampak penggunaan gawai terhadap perkembangan anak. Sari pediatri. 2018;20(2):101-105. doi:10.14238/ sp20.2.2018.101-5

22. Lin HP, Chen KL, Chou W, et al. Prolonged touch screen device usage is associated with emotional and behavioral problems, but not language delay, in toddlers. Infant Behav Dev. 2020;58:101424. doi: 10.1016/j.infbeh.2020.101424 